\title{
Sulfonyl-bridged calix[4]arene as an inhibitor \\ of protein tyrosine phosphatases
}

\author{
Vladyslav M. Buldenko ${ }^{a}$, Oleksandr L. Kobzar ${ }^{\mathrm{a}}$, Viacheslav V. Trush $^{\mathrm{a}}$, Andriy B. Drapailo ${ }^{\mathrm{b}}$, \\ Vitaly I. Kalchenko ${ }^{\mathrm{b}}$, Andriy I. Vovk ${ }^{\mathrm{a}^{*}}$ \\ ${ }^{a}$ Institute of Bioorganic Chemistry and Petrochemistry of the National Academy of Sciences of \\ Ukraine, Murmanska Street, 1, Kyiv-94 02094, Ukraine \\ ${ }^{b}$ Institute of Organic Chemistry of the National Academy of Sciences of Ukraine, \\ Murmanska Street, 5, Kyiv-94 02094, Ukraine \\ vovk@,bpci.kiev.ua
}

Keywords: sulfonylcalix[4]arene, protein tyrosine phosphatase MEG2, PTP1B, inhibition, molecular docking.

Previously, phosphonic acid derivatives of calix[4]arene and thiacalix[4]arene were found to be potential inhibitors of protein tyrosine phosphatase $1 \mathrm{~B}$. In the present paper, the inhibitory activity of unsubstituted sulfonyl-bridget calix[4]arene towards some of the therapeutically important protein tyrosine phosphatases has been established. The obtained results showed that the sulfonylcalix[4]arene is able to inhibit protein tyrosine phosphatase MEG2 with $\mathrm{IC}_{50}$ value in the micromolar range. At the same time, the inhibitor demonstrated lower activity in case of other protein tyrosine phosphatases such as PTP1B, MEG1, TC-PTP, SHP2, and PTP $\beta$. The performed molecular docking indicated that the inhibitor binds to the active site region of MEG2 and PTP1B with WPD-loop in the open conformation.

\section{Introduction}

Enzymes belonging to superfamily of protein tyrosine phosphatases (PTPs) catalyze protein tyrosine dephosphorylation in diverse biological processes including cell growth, differentiation, metabolism, and apoptosis [1,2]. Protein tyrosine phosphatase 1B (PTP1B) negatively regulates insulin and leptin signaling pathways in human cells. Hyperactivity of this enzyme may promote type 2 diabetes and obesity $[3,4]$.
T-cell protein tyrosine phosphatase (TC-PTP) was found to be linked with cellular leptin resistance, development of type 1 diabetes, and inflammation $[5,6]$. The activity of $\mathrm{SH} 2$ domain-containing protein tyrosine phosphatase-2 (SHP2) plays a fundamental role in oncogenic signaling pathways $[7,8]$. Protein tyrosine phosphatase MEG2, originally cloned from a megakaryocytic cell line, modulates ErbB2 and EGFR signaling in breast cancer 
cells [9]. Recent studies have identified MEG2 as a negative regulator of vascular EGFR signaling and function in endothelial cells [10]. This enzyme may also be responsible for insulin signaling and glucose homeostasis in dietinduced obese mice [11]. Therefore, a possibility to control the activity of the PTPs may decrease risk of developing the pathologies. This demands more effective and selective inhibitors of PTPs to create new therapeutics $[12,13]$.

Calix[4]arenes represent macrocyclic three-dimensional molecules which are widely studied for their applications in bioorganic chemistry and medicine [14-17]. Some of calix[4]arene derivatives have low toxicity [1719] and were found to exhibit antibacterial [20,21], antiviral [22,23], and anticancer activities [24,25]. These compounds can also be useful for biochemical recognition and separation of amino acids, nucleotides, carbohydrates, and steroids [26].

Because of unique structure, calix[4]arenes can efficiently and selectively target enzymes and other proteins. The calix[4]arene derivatives with a non-cleavable phosphonic acid groups, which mimic the phosphorylated tyrosine fragment, effectively inhibit PTP1B in vitro with micromolar $\mathrm{IC}_{50}$ values being less effective inhibitors of some other human PTPs [27-29]. The high inhibitory activities of the calix[4]arene phosphonic acids were attributed to the synergistic effects of the phosphonate fragments and calix[4]arene scaffold involved in the interaction with the enzyme. The multivalent properties of the macrocyclic inhibitors such as size, conformation, and amphiphilicity are important for their activity [30]. Our next efforts for designing inhibitors of PTPs had been directed towards thiacalix[4]arene 2 (Figure 1) which differs from calix[4]arene 1 due to possibility for functionalization not only at the upper or lower rim but also at the bridging sulfide groups [31]. Sulfonylcalixarenes, which contain four bridging $\mathrm{SO}_{2}$-groups, are considered as building blocks to construct macrocyclic containers [32].

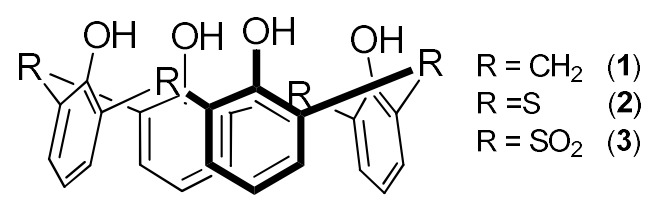

Figure 1. Structures of calix[4]arene, thiacalix[4]arene, and sulfonylcalix[4]arene.

In this paper, we showed that unsubstituted sulfonyl-bridged calix[4]arene $\mathbf{3}$ can exhibit remarkable properties as a molecule with biological activity being able to target PTPs. To get insight into the selectivity of action of the sulfonylcalix[4]arene $\mathbf{3}$, we evaluated its inhibitory activity against a panel of PTPs as well as employed molecular docking studies.

\section{Experimental part}

Commercially available PTP1B, TCPTP, MEG1, MEG2, SHP2, and PTP $\beta$ were 
used to study the inhibitory properties of calix[4]arenes in vitro. The activities of PTPs were determined by following the changes in concentration of $p$-nitrophenol released during hydrolysis of $p$-nitrophenyl phosphate as a substrate. Values of $\mathrm{IC}_{50}$ were calculated from a dose-dependent curve as the concentration of the inhibitor which decreased the enzyme activity to $50 \%$ Calix[4]arene $\mathbf{1}$, thiacalix[4]arene 2, and sulphonylcalix[4]arene 3 (Figure 1) were synthesized according to the previously developed protocols [33-35].

Enzymatic reaction was carried out at 25 ${ }^{\circ} \mathrm{C}$ (MEG1, MEG2, PTP1B), and $30{ }^{\circ} \mathrm{C}$ (TCPTP, SHP2, РTP $\beta$ ). The assay solution contained $50 \mathrm{mM}$ Bis-Tris ( $\mathrm{pH}$ 7.2), 1 vol. \% of dimethyl sulfoxide, $100 \mathrm{mM} \mathrm{NaCl}, 2 \mathrm{mM}$ DTT, $3 \mathrm{mM}$ EDTA. The substrate concentrations in experiments with different concentrations of sulfonylcalix[4]arene were of $2 \mathrm{mM}$ for PTP1B, TC-PTP, $6 \mathrm{mM}$ for MEG1, MEG2, SHP2, and 1 $\mathrm{mM}$ for PTP $\beta$, which corresponds to $K_{m}$ values of the enzymes. The final volume of assay solution was $0.5 \mathrm{~mL}$. The mixture was preincubated for $5 \mathrm{~min}$, and the reaction was initiated by addition of the enzyme (4-8 $\mathrm{nM}$ in the reaction mixture). The released $p$ nitrophenol was determined by reading the absorbance at $410 \mathrm{~nm}\left(\varepsilon=18000 \mathrm{M}^{-1} \mathrm{~cm}^{-1}\right)$.

Hill coefficients were calculated from four parameter equation by GraphPad Prism program. Hydropathicity of amino acid residues of the enzyme active sites was calculated as the grand average of hydropathicity (GRAVY) scores [36] by ProtParam Tool of the Expert Protein Analysis System (ExPASy) proteomics server of the Swiss Institute of Bioinformatics.

Blind docking studies were performed by the AutoDock Vina [37] program using Xray crystals structures of MEG2 (PDB codes: 2PA5 (open WPD-loop) and 4ICZ (closed WPD-loop)) and centroids of PTP1B clasters [38] (PDB codes: 1NL9, 1OEM, 1PHO, 1Q6M, 2CM8, 2CNF, 2HNP). Three dimensionalstructures of four ligand conformers were optimized with MMFF94s force field (by Avogadro program) [39]. The conformers were docked to the A-chain of PTPases or to the Xchain in case of 1OEM X-ray crystal. The presented ligands, and water molecules were removed from PDB-files before calculations. Docking of conformers directed into active site of MEG2 and PTP1B were performed by the program AutoDock 4.2 [40].

\section{Results and discussion}

The data presented in Figure 2 demonstrate the inhibition effects of sulphonylcalix[4]arene 3 towards PTP1B, TCPTP, and MEG1. Among them, the sulphonylcalix[4]arene was found to be a good inhibitor of MEG2 $\left(\mathrm{IC}_{50}=1.4 \pm 0.48 \mu \mathrm{M}\right)$ with modest selectivity over PTP1B $\left(\mathrm{IC}_{50}=4.5 \pm 0.5\right.$ $\mu \mathrm{M})$ and much higher selectivity over TC-PTP $\left(\mathrm{IC}_{50}=18.9 \pm 3.8 \mu \mathrm{M}\right)$. 


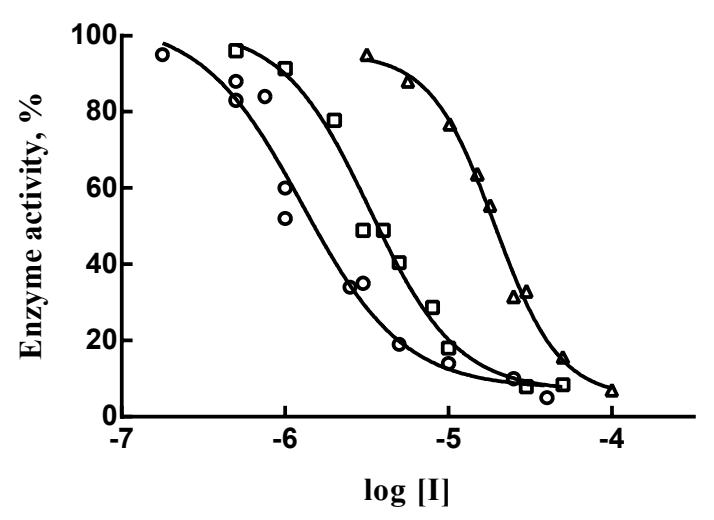

Figure 2. Dose-dependent inhibition of MEG2 (०), PTP1B (ם), and TC-PTP $(\Delta)$ by sulphonylcalix[4]arene 3.

The macrocycle exhibited low activity towards $\mathrm{SHP} 2\left(\mathrm{IC}_{50}=49 \pm 9 \mu \mathrm{M}\right)$ and $\mathrm{PTP} \beta$ $\left(\mathrm{IC}_{50}=39 \pm 9 \mu \mathrm{M}\right)$ and only slightly reduced the activity of MEG1 at concentration of $50 \mu \mathrm{M}$. Calixarene 1 and thiacalixarene $\mathbf{2}$ which have a limited solubility in water were not active at the concentration of $20 \mu \mathrm{M}$.

The Hill slopes calculated from the dosedependent curves of inhibition of MEG2, PTP1B, and TC-PTP by compound 3 (Figure 2) are $1.4 \pm 0.35,1.6 \pm 0.33$, and $2.2 \pm 0.34$, respectively. This indicates that at least one binding site of the enzymes is involved in the inhibition mechanism.

It is known that active site of PTP is highly conserved. To accommodate a substrate, the active surface should carry a positive charge and provide hydrophobic environment [41]. As compared to macrocycles $\mathbf{1}$ and $\mathbf{2}$, sulphonylcalix[4]arene $\mathbf{3}$ is more negatively charged, which can facilitate the binding to the active site. The results of hydropathicity analysis of PTP1B, TC-PTP, MEG2, SHP2, and PTP $\beta$ showed that hydrophobic character of MEG2 active surface including pTyr-loop, Rloop, WPD-loop, P-loop, and Q-loop [42,43] may promote hydrophobic interactions with the bulky sulphonylcalix[4]arene molecule.

Molecular modeling was performed for understanding binding modes of sulphonylcalix[4]arene 3 at the active sites of MEG2 and PTP1B. X-Ray crystals of PTP1B and MEG2 are represented by two groups of structures with open or closed WPD-loop [43], and sulfonylcalix[4]arene like calix[4]arene skeleton can exist in four conformations $[44,45]$. Blind docking of four conformers to entire surface of MEG2 and PTP1B showed the possibility of existence of several binding sites. Among them, the active site region with the open WPD-loop was the most favorable for the inhibitor binding. According to the docking results, the lowest binding energies were obtained for pinched cone conformer (Table 1). The complex of compound 3 with MEG2 (Fig. $3 \mathrm{~A})$ showed that $\mathrm{OH}$-groups at the lower rim interact with Lys411 and Arg521, while sulfonyl groups form H-bonds with Tyr333, Trp468, Lys411, Ser516, Ala517, Gly520, and Arg521. The inhibitor takes part in aromaticaromatic interaction with Tyr333 and aromaticcation interaction with Arg409 and Arg521. In addition, hydrophobic contacts were observed with Ala517, Ile519, and Tyr471. 
Table 1. Estimated binding energy (Auto Dock 4.2) of sulfonylcalix[4]arene conformers in the active sites of MEG2 (PDB code 4GE2) and PTP1B (PDB code 1PH0).

\begin{tabular}{c|c|c}
\hline \multirow{2}{*}{ Conformer } & \multicolumn{2}{|c}{$\Delta \mathrm{G}(\mathrm{kcal} / \mathrm{mol})$} \\
\cline { 2 - 3 } & MEG2 & PTP1B \\
\hline pinched cone & -9.64 & -8.66 \\
partial cone & -7.69 & -7.38 \\
1,2-alternate & -8.15 & -7.61 \\
1,3-alternate & -6.66 & -6.68 \\
\hline
\end{tabular}

At the same time, the ligand located at the active site of PTP1B (Fig. 3B) has a slightly different position from that in complex with MEG2. It may be due to the fact that Lys116 and Ser118 of R-loop of PTP1B are represented by Glu407 and Arg409 in the structure of MEG2. The hydroxyl groups at the lower rim of sulfonylcalix[4]arene form H-bonds with Glu115, Lys116 and Asp181. The sulfonyl groups have hydrogen bonds with Lys116, Lys120, Trp179, Arg221, and Gln266. The aromatic-cation interactions are observed with Lys120 and Arg221.

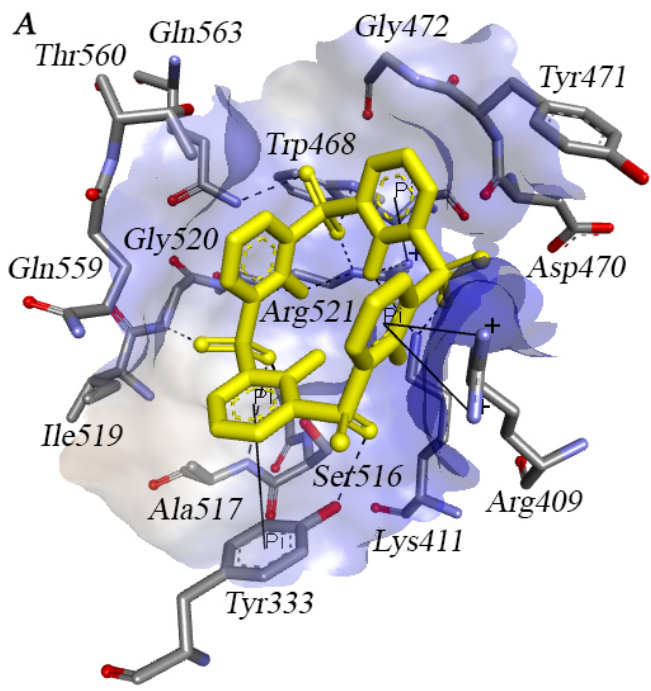

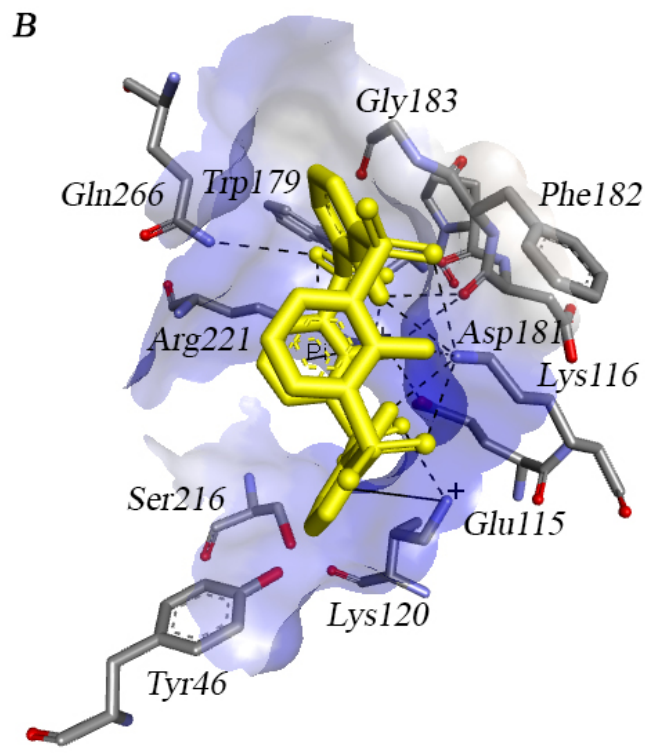

Figure 3. The posible binding modes of sulfonylcalix[4]arene at the active site of MEG2 (A) and PTP1B (B).

\section{Conclusions}

Unsubstituted sulfonyl-bridged calix[4]arene 3 turned out to be promising bioactive compound with inhibitory activity towards protein tyrosine phosphatase MEG2 and selectivity over some PTPs. Molecular docking showed the possible binding modes of calix[4]arene 3 to MEG2 and PTP1B. H-bonds and hydrophobic interactions may contribute to the stability of the enzyme-inhibitor complex. These data provide a basis for further investigation of sulphonylcalix[4]arene derivatives in searching for substances with desired biological properties.

\section{References}

[1] Alonso A., Sasin J., Bottini N., Friedberg I., Osterman A., Godzik A., Hunter T., Dixon J., Mustelin. 
Protein tyrosine phosphatases in the human genome. Cell. 2004; 11: 699-711.

[2] Zhang Z. Y. Protein tyrosine phosphatases: structure and function, substrate specificity, and inhibitor development. Annu. Rev. Pharmacool. Toxicol. 2002; 42: 209-234.

[3] Elchebly M., Payette P., Michaliszyn E., Cromlish W., Collins S., Loy A. L., Ramachandran C. Increased insulin sensitivity and obesity resistance in mice lacking the protein tyrosine phosphatase-1B gene. Science. 1999; 283: 1544-1548.

[4] Lund I.K., Hansen J.A., Andersen H.S., Møller N. P. H., Billestrup N. Mechanism of protein tyrosine phosphatase 1B-mediated inhibition of leptin signaling. J. Mol. Endocrinol. 2005; 34(2): 339-351.

[5] Galic S., Hauser C., Kahn B. B., Haj F.G., Neel B. G., Tonks N. K., Tiganis T. Coordinated regulation of insulin signaling by the protein tyrosine phosphatases PTP1B and TCPTP. Mol. Cell. Biol. 2005; 25(2): 819-829.

[6] Chistiakov D.A., Chistiakova E.I. T-cell protein tyrosine phosphatase: A role in inflammation and autoimmunity. Int. J. Diabetes Mellit. 2010; 2: 114-118.

[7] Wang S., Yu W.M., Zhang W., McCrae K. R., Neel B.G., Qu C.K. Noonan syndrome/leukemiaassociated gain-of-function mutations in SHP-2 phosphatase (PTPN11) enhance cell migration and angiogenesis. J. Biol. Chem. 2009; 284(2): 913-920.

[8] Aceto N., Sausgruber N., Brinkhaus H., Gaidatzis D., Martiny-Baron G., Mazzarol G., Pachkov M. Tyrosine phosphatase SHP2 promotes breast cancer progression and maintains tumor-initiating cells via activation of key transcription factors and a positive feedback signaling loop. Nat. Med. 2012; 18: 529-537.

[9] Yuan T., Wang Y., Zhao Z. J., Gu H. J. Protein-tyrosine phosphatase PTPN9 negatively regulates ErbB2 and epidermal growth factor receptor signaling in breast cancer cells. J. Biol. Chem. 2010; 285:14861-14870.
[10] Hao Q., Samten B., Ji H., Zhao Z. J., Tang H. Tyrosine phosphatase PTP-MEG2 negatively regulates vascular endothelial growth factor receptor signaling and function in endothelial cells. Am. J. Physiol. Cell Physiol. 2012; 303: 548-553.

[11] Zhang S., Liu S., Tao R., Wei D., Chen L., Shen W., Zhang Z. Y. A highly selective and potent PTPMEG2 inhibitor with therapeutic potential for type 2 diabetes. J. Am. Chem. Soc. 2012; 134: 18116-18124.

[12] Vintonyak V. V., Antonchick A. P., Rauh D. Waldmann H. The therapeutic potential of phosphatase inhibitors. Curr. Op. in Chem. Biol. 2009; 13: 272-283.

[13] Barr A. J. Protein tyrosine phosphatases as drug targets: strategies and challenges of inhibitor development. Future Med. Chem. 2010; 2(10): 15631576.

[14] Sansone F., Segura M., Ungaro R. Calixarenes in bioogranic and biomimetic chemistry. Dodrecht: Kluwer Academic Publishers; 2001. p. 496512 .

[15] Tauran Y. W., Coleman A., Perret F., Kim B. Cellular and in vivo biological activities of the calix[n]arenes. Curr. Org. Chem. 2015; 19(23): 22502270 .

[16] Nimse S.B., Kim T. Biological applications of functionalized calixarenes. Chem. Soc.Rev. 2013; 42 (1): 366-386.

[17] Rodik R. V., Boyko V. I., Kalchenko V. I. Calixarenes in bio-medical researches. Curr. Med. Chem. 2009; 16: 1630-1655.

[18] Miller-Shakesby D. M., Burke B. P., Nigam S., Stasiuk G. J., Prior T. J., Archibald S. J., Redshaw C. Synthesis, structures and cytotoxicity studies of psulfonatocalix [4] arene lanthanide complexes. CrystEngComm, 2016; 18(26); 4977-4987.

[19] Rodik R. V., Anthony A. S., Kalchenko V. I., Mély Y., Klymchenko A. S. Cationic amphiphilic calixarenes to compact DNA into small nanoparticles for gene delivery. New J. Chem. 2015; 39(3): 1654-1664. 
[20] Dibama H. M., Clarot I., Fontanay S., Salem A. B., Mourer M., Finance C., Regnouf-de-Vains J. B. Towards calixarene-based prodrugs: Drug release and antibacterial behaviour of a water-soluble nalidixic acid/calix [4] arene ester adduct. Bioorg. Med. Chem. Lett. 2009; 19: 2679-2682.

[21] Patel M. B., Modi N. R., Raval J. P., Menon S. K. Calix[4]arene based 1,3,4-oxadiazole and thiadiazole derivatives: Design,synthesis, and biological evaluation. Org. Biomol. Chem. 2012; 10: 1785 - 1794.

[22] Tsou L. K., Dutschman G. E., Gullen E. A., Telpoukhovskaia M., Cheng Y.-C., Hamilton A. D. Discovery of a synthetic dual inhibitor of HIV and HCV infection based on a tetrabutoxy-calix [4] arene scaffold. Bioorg. Med. Chem. Lett. 2010; 20: 2137 - 2139.

[23] Mourer M,; Psychogios N., Laumond G., Aubertin A.-M., Regnouf-de-Vains J.-B. Synthesis and anti-HIV evaluation of water-soluble calixarene-based bithiazolyl podands. Bioorg. Med. Chem. 2010: 18. 36 45.

[24] Yousaf A., Hamid S. A., Bunnori N. M., Ishola A.A. Applications of calixarenes in cancer chemotherapy: facts and perspectives. Drug Des. Dev. Ther. 2015; 9: 2831-2838.

[25] Santos D., Medeiros-Silva J., Cegonho S., Alves E., Ramilo-Gomes F., Santos A. O., Cruz C. Cell proliferation effects of calix[4]arene derivatives. Tetrahedron. 2015; 71(40); 7593-7599.

[26] Shimojo K., Oshima T., Naganawa H., Got M. Calixarene-Assisted Protein Refolding via LiquidLiquid Extraction. Biomacromolecules. 2007; 8: 30613066.

[27] Trush V. V., Cherenok S. O., Tanchuk V. Yu., Kukhar V. P., Kalchenko V. I., Vovk A. I. Calix [4] arene methylenebisphosphonic acids as inhibitors of protein tyrosine phosphatase 1B. Bioorg. Med. Chem. Lett. $2013 ; 23(22): 5619-5623$.

[28] Trush V. V., Tanchuk V. Y., Cherenok S. O., Kalchenko V. I., Vovk A. I. Calix[4]arene $\alpha$ hydroxymethylphosphonic acids as potential inhibitors of protein tyrosine phosphatases. J. Org. Pharm. Chem. $2014 ; 12 ; 39-42$.

[29] Trush V. V., Tanchuk V. Y., Cherenok S. O., Kalchenko V. I., Vovk A. I. Evaluation of inhibition of protein tyrosine phosphatase 1B by calixarene-based $\alpha$ ketophosphonic acids. Chem. Biol. Lett. 2015; 2: 1-5.

[30] Giuliani M., Morbioli I., Sansone F., \& Casnati A. Moulding calixarenes for biomacromolecule targeting. Chem. Com. 2015; 51(75): 14140-14159.

[31] Trush V. V., Kharchenko S. G., Tanchuk V. Yu., Kalchenko V. I., Vovk A. I. Phosphonate monoesters on a thiacalix[4]arene framework as potential inhibitors of protein tyrosine phosphatase 1B. Org. Biomol. Chem. 15; 13: 8803-8806.

[32] Dai F.-R., Wang Z. Modular Assembly of Metal-Organic Supercontainers Incorporating Sulfonylcalixarenes. J. Am. Chem. Soc. 2012; 134: 8002-8005.

[33] Gutsche C. D., Dhawan B., No K. H., Muthukrishman R. The synthesis, characterization, and properties of the Calixarenes from p-tert-butylphenol. J. Am. Chem. Soc. 1981; 103: 3782-3791.

[34] Kumagai H., Hasegawa M., Miyanari S., Sugawa Y., Sato Y., Hori T., Miyano S. Facile Synthesis of p-tert-Butylthiacalix[4]arene by the reaction p-tertButylphenol with Elemental Sulfur in the Presence of Base. Tetrahedron Lett. 1997; 38: 3971-3972.

[35] Iki N., Kumagai H., Morohashi N., Ejima K., Hasegawa M., Miyanari S., Miyano S. Selective oxidation of thiacalix[4]arenes to the sulfinyl- and sulfonilcalix[4]arenes and their coordination ability to metal ions. Tetrahedron Lett. 1998; 39: 7559-7562.

[36] Kyte J., Doolittle R. F. A simple method for displaying the hydropathic character of a protein. J. Mol. Biol. 1982; 157(1); 105-132.

[37] Trott O., Olson A. J. AutoDock Vina: improving the speed and accuracy of docking with a new scoring function, efficient optimization, and multithreading. J. Comput. Chem. 2010; 31: 455 - 461. 
[38] Tanchuk V. Yu., Tanin V. O., and Vovk A.

I. Classification of binding site conformations of protein tyrosine phosphatase 1B. Chem. Biol. Drug Des. 2012; 80: 121-128.

[39] Hanwell M. D., Curtis D. E., Lonie D. C. Vandermeersch T., Zurek E., Hutchison G. R. Avogadro: an advanced semantic chemical editor, visualization, and analysis platform. J. Cheminform. 2012; 4: 17.

[40] Huey R., Morris G. M., Olson A. J., Goodsell D. S. A semiempirical free energy force field with charge-based desolvation. J. Comput. Chem. 2007; 28: 1145-1152.

[41] Andersen J. N., Mortensen O. H., Peters G. H., Drake P. G., Iversen L. F., Olsen O. H., Jansen P. G., Andersen H. S, Tonks N. K., Moller P. H. Structural and evolutionary relationships among protein tyrosine phosphatase domains. Mol. Cell. Biol. 2001; 21; 71177136.

[42] Tautz L., Critton D. A., Grotegut S.. Protein tyrosine phosphatases: structure, function, and implication in human disease. Methods Mol Biol. 2013; 179-221.

[43] Kamerlin S. C. L., Rucker R., Boresch. S. A targeted molecular dynamics study of WPD loop movement in PTP1B. Biochem. Biophys. Res. Commun. 2006; 345.3: 1161-1166.

[44] Wanno B., Sang-aroon W., Tuntulani T., Polpoka B., Ruangpornvisuti V. Conformational and energetical structures of sulfonylcalix [4] arene, p-tertbutylsulfonylcalix [4] arene and their zinc complexes. J. Molecular Struct. (Theochem)2003; 629.1: 137-150.

[45] Gutsche C. D. Dhawan B., Levine J. A., No K. H., Bauer L. J. Calixarenes 9: conformational isomers of the ethers and esters of calix [4] arenes. Tetrahedron 1983; 39.3: 409-426. 